\title{
Editorial
}

\section{Introduction to Heckscher-Ohlin theory: A modern approach}

When does a model become a paradigm? The Lucas (1972) model earned its inventor the Sveriges Riksbank Prize in Economic Sciences in Memory of Alfred Nobel in 1995, but the Heckscher-Ohlin-Vanek paradigm merited one of its progenitors only half the prize in 1977. Kuhn (1962) coined the modern usage of "paradigm," which the Merriam-Webster Online dictionary defines as "a philosophical and theoretical framework of a scientific school or discipline within which theories, laws, and generalizations and the experiments performed in support of them are formulated; broadly: a philosophical or theoretical framework of any kind." This volume is the defense of an economic paradigm, almost a century old, that has found broad applications in international economics, development economics, public finance, economic geography, labor economics, and applied general equilibrium theory.

The great economic historian Heckscher (1919) had the germ of the idea that his student Ohlin (1933) popularized, but Vanek (1968) made the theory operational. Vanek defined the chain of factor abundance, and he wrote the explicit algebra that forms all subsequent empirical tests of the theory. His most lasting contribution was to emphasize that trade in goods is only a veil; Heckscher-Ohlin theory is really about the trade in the underlying factor services. Few modern readers are aware of how well done the empirical analysis in Vanek (1963) really was. In my opinion, that careful empirical work led to the seminal theory for which Vanek is rightfully celebrated.

Of course, the paradigm is quite vulnerable; this Achilles has two weak heels. First, countries most assuredly do not share a common technology. Second, the services of otherwise identical factors earn disparate rewards, depending on the vagaries of birth or location. It was one thing to assume that countries have identical technologies and that trade equalizes factor prices, but it is quite another matter to be confronted with reality that wages in Bangladesh and the United States differ by an order of magnitude. The articles in this issue are unified around the theme that simple versions of the Heckscher-Ohlin-Vanek paradigm have not fared well empirically. This observation is not new; Leontief (1953) and Leamer (1984) are its most eloquent early advocates. What is new, in this volume, is the way we deal with these obvious blemishes.

Vanek (in press) reviews the history of thought on the factor content of trade, and he offers a sobering vision of the policy implications of large wage disparities. Having spent a lifetime concerned with social justice, Professor Vanek warns about destructive trade when factor prices are not equalized. Vanek's warnings to policy makers come at the end of the deepest recession in the world economy since the Second War. In a complementary analysis, Soo (2011) examines economic welfare in a model where resources and technologies differ across countries. He predicts that both factors of production may experience gains from trade if countries have sufficiently similar endowments.

Baskaran, Blöchl, Brück, \& Theis (in press) contribute to the exciting new field of networks in social systems. They look at a different trading network for each good. Their empirical analysis shows that differences in endowments are correlated with bilateral trade when network connections are dense. In essence, when a good is traded competitively on world markets, then Heckscher-Ohlin Theory predicts bilateral trade well.

Egger, Marshall, \& Fisher (in press) differentiate between trade owing to differences in technology and that arising because of differences in endowments. They implement the natural decomposition inherent in the concept of a virtual endowment invented by Fisher and Marshall (2008). A virtual endowment is the vector of actual factor services that a country would need to produce its output if the assumptions of the Heckscher-Ohlin-Vanek paradigm held exactly. These authors show that endowment differences predict the lion's share of the factor content of trade, although differences in technology can matter too.

Artal-Tur, Castillo-Giménez, Llano-Verduras, \& Requena-Silvente (in press) hark back to Ohlin's early observation and apply the paradigm to the seventeen regions of Spain. They show that technological differences matter among the provinces of a national 
economy, even though factor price differences among the regions are not deemed important. It is significant that the technology matrix of Andalusia is quite highly correlated with the overall matrix for Spain, but those of the Balearic Islands and the Canary Islands are quite different from the national matrix. This work shows clearly that one needs a tractable theory of technical differences if one wants to give the paradigm a chance.

Reimer (in press) argues that the factor content of trade ought to depend upon the stages of value added for final goods whose components are produced in several different countries. If a traded good has some value added that was produced domestically, then the factor content of trade is mismeasured. Using a sample of fourteen countries, Reimer calculates that about one-fifth of the factor content of trade represents the services of local factors.

Using annual data from the United States from the last half century, Thompson (in press) estimates the comparative statics of the $2 \times 2$ Heckscher-Ohlin model in an innovative manner. Thompson also incorporates modern time series econometrics in his analysis. He shows a very strong magnification effect for labor, arguing that $1 \%$ decrease in the labor force would raise real wages by $9.7 \%$.

Fisher (in press) offers a new theoretical perspective, arguing that the local factor content of foreign Rybczynski effects is the key to understanding international technological differences. His goal is to use careful theory to put the Heckscher-Ohlin-Vanek paradigm back on a solid empirical footing. This work is a first step in quantifying how to measure general technical differences that are neither Hick-neutral nor factor-specific. It shows how to describe cogently the kinds of technological differences that Artal-Tur et al. (in press) document.

Kuhn, (1962) emphasizes that the process of replacing a scientific paradigm is not linear. Research in our field in the last three decades has featured models of imperfect competition and heterogeneous firms, leading some to doubt the empirical relevance of the Heckscher-Ohlin-Vanek paradigm. The papers in this issue show that it has yet to face the full-on assault from scientific revolutionaries who will overrun it.

\section{References}

Artal-Tur, A., Castillo-Giménez, J., Llano-Verduras, C., \& Requena-Silvente, F. (in press). The factor content of regional bilateral trade: The role of technology and demand. International Review of Economics and Finance.

Baskaran, T., Blöchl, F., Brück, T., \& Theis, F. (in press). The Heckscher-Ohlin model and the network structure of international trade. International Review of Economics and Finance.

Egger, P., Marshall, K. G., \& Fisher, E. O. (in press). Empirical foundations for the resurrection of Heckscher-Ohlin theory. International Review of Economics and Finance.

Fisher, E.O., Marshall, K.G., 2008. The factor content of trade when countries have different technologies. Unpublished manuscript http://www.calpoly.edu/efisher/ FCT.pdf

Fisher, E. O. (in press). Heckscher-Ohlin theory when countries have different technologies. International Review of Economics and Finance.

Heckscher, E. (1919). Utrikeshandelns verkan på inkomstfördelningen. några teoretiska grundlinjer. Ekonomisk tidskrift, $21,1-32$.

Kuhn, T. S. (1962). The structure of scientific revolutions. Chicago: University of Chicago Press.

Leamer, E. E. (1984). Sources of international comparative advantage: Theory and evidence. Cambridge, MA: The MIT Press.

Leontief, W. (September 1953). Domestic production and foreign trade: The American capital position re-examined. Proceedings. American Philosophical Society, 97(4), 332-349.

Lucas, R. (April 1972). Expectations and the neutrality of money. Journal of economic theory, 4(2), $103-124$.

Ohlin, B. (1933). Interregional and international trade. Harvard University Press.

Reimer, J. J. (in press). The domestic content of imports and the foreign content of exports. International Review of Economics and Finance.

Soo, K. T. (2011). The gains from trade revisited. International Review of Economics and Finance.

Thompson, H. (in press). Estimating the Heckscher-Ohlin model: Inverting the inverse matrix. International Review of Economics and Finance.

Vanek, J. (1963). The natural resource content of United States foreign trade, 1870-1955. Cambridge, MA: The MIT Press.

Vanek, J. (November 1968). The factor proportions theory: The n-factor case. Kyklos, 21(4), 749-756.

Vanek, J. (in press). From great depression to great recession. International Review of Economics and Finance.

Eric O'N. Fisher 